\title{
Brand Trust dan Promosi Penjualan Terhadap Keputusan Pembelian Produk Di Masa Covid-19
}

\author{
Amelda Pramezwary ${ }^{1}$, Juliana $^{2}$, Jennifer Winata ${ }^{3}$, Roselynn Tanesha ${ }^{4}$, Tiffanysius Armando ${ }^{5}$ \\ 1,2,3,4,5 Fakultas Pariwisata, Universitas Pelita Harapan \\ E-mail: ${ }^{1}$ julianawijaya9784.jw@gmail.com, ${ }^{2}$ juliana.stpph@uph.edu, ${ }^{3}$ jennifer.winata@gmail.com, \\ ${ }^{4}$ roselynn.tanesha@gmail.com, ${ }^{5}$ tiffanysius.armando@gmail.com
}

\begin{tabular}{ccc}
\hline Diterima & Direvisi & Disetujui \\
$03-12-2021$ & $10-01-2021$ & $19-01-2021$ \\
\hline
\end{tabular}

\begin{abstract}
Abstrak - Adanya pandemi covid-19 membuat semua industri terdampak, begitu juga dengan coffee shop. Menghadapi adanya pandemi ini, brand trust dan promosi penjualan menjadi salah satu fokus utama dari strategi coffee shop. Brand trust terdiri dari kepercayaan, rasa aman dan kejujuran terhadap konsumen. Promosi penjualan terdiri dari frekuensi, kuantitas, waktu dan ketepatan sasaran promosi. Tujuan dari penelitian ini adalah untuk menganalisis adanya pengaruh positif dari brand trust dan promosi penjualan terhadap keputusan pembelian konsumen Starbucks pada masa covid-19. Penelitian dilakukan secara online dengan menyebarkan kuesioner melalui google forms kepada 200 responden dengan menggunakan Penelitian ini menggunakan metode kuantitatif untuk menganalisis data yang diperoleh dengan uji validitas dan uji reliabilitas, uji regresi linier berganda, uji koefisien determinasi dan uji F serta uji t, yang diolah dengan program SPSS. Hasil penelitian menunjukkan bahwa promosi penjualan dan brand trust menunjukkan pengaruh yang signifikan terhadap keputusan pembelian konsumen Starbucks pada masa covid-19. Brand Trust merupakan variabel yang menunjukkan pengaruh paling signifikan dalam penelitian ini, terutama di masa covid-19 dimana konsumen lebih tertarik dengan brand Starbucks Coffee dibandingkan merek coffee shop lainnya.
\end{abstract}

Kata Kunci: Brand Trust, Promosi Penjualan, Keputusan Pembelian

\begin{abstract}
The covid-19 pandemic affected all industries, as well as coffee shops. Facing this pandemic, brand trust and sales promotion are the main focuses of the coffee shop strategy. Brand trust consists of trust, a sense of security and honesty with consumers. Sales promotion consists of frequency, quantity, timing and accuracy of promotion targets. The purpose of this study was to analyze the positive influence of brand trust and sales promotion on Starbucks consumer purchasing decisions during the Covid-19 period. The research was conducted online by distributing questionnaires via Google Forms to 200 respondents using this research using quantitative methods to analyze the data obtained with validity and reliability tests, multiple linear regression, determination coefficient test and F test and t test, which were processed using the SPSS program. The results showed that sales promotion and brand trust showed a significant influence on Starbucks consumer purchasing decisions during the covid-19 period. Brand Trust is a variable that shows the most significant influence in this study, especially during the Covid-19 period where consumers are more interested in the Starbucks Coffee brand than other coffee shop brands.
\end{abstract}

Key Words: Brand Trust, Sales Promotion, Purchase Decision

\section{PENDAHULUAN}

Perkembangan dalam industri food and beverage mengenai kopi mengalami banyak kemajuan. Hal ini dikuatkan berdasarkan Gabungan Eksportir dan Industri Kopi Indonesia (Gaeki) pada akhir 2019 bahwa konsumsi kopi di Indonesia akan mencatat kenaikan $8 \%$ setiap tahunnya. Dengan adanya peluang yang begitu besar dari produk kopi ini, maka para entrepreneur ataupun franchise mulai mendirikan tempat yang menyajikan kopi sebagai produk utama ataupun product tambahan mereka yang biasanya dapat ditemui di café, warung, grocery store, supermarket, hingga coffee shop. Banyaknya ragam produk kopi yang ditawarkan membuktikan adanya permintaan yang besar dari produk kopi di Indonesia. Terutama di saat ini kegiatan minum kopi sudah menjadi lifestyle dalam masyarakat, hal ini bisa dilihat dengan banyaknya gerai coffee shop di Indonesia seiring berjalannya waktu. Coffee shop bagi masyarakat, bukan hanya menjadi tempat untuk sekedar minum kopi, namun juga sebagai tempat berkumpul, pertemuan ataupun acara spesial lainnya. Menurut (Sumarsono, 2015) Coffee Shop adalah restoran informal yang tidak menggunakan table service seperti restoran fine dining, namun berfokus 
pada hidangan kopi dan minuman lainnya.

Dengan persaingan dalam industri yang kuat maka, membuat coffee shop tidak hanya menjual kegunaan produk saja, tetapi juga bisa dikaitkan dengan brand trust dan promosi penjualan dari coffee shop itu sendiri. Starbucks Corporation atau lebih dikenal dengan sebutan 'Starbucks' adalah perusahaan kedai kopi (coffee shop) global asal Amerika Serikat tepatnya di Seattle, Washington. Starbucks merupakan coffee shop yang terkenal di berbagai negara, salah satunya di Indonesia. Coffee shop yang satu ini memiliki 326 gerai yang tersebar di 22 kota di Indonesia yang dilengkapi dengan layanan drive thru, take away, dine-in, delivery bahkan coffee class di gerai tertentu. Starbucks bahkan diakui sebagai coffeehouse chain terbesar yang ada di dunia, yang terus mengalami peningkatan dari awal 70an sampai pertengahan 2019.

Namun, saat adanya pandemi covid-19 yang pertama kali terdeteksi pada akhir 2019, penjualan Starbucks mulai menunjukkan penurunan yang cukup signifikan sampai pada tahun 2020. Akibat dari covid-19 yang mulai menyebar di berbagai dunia, penjualan Starbucks di Indonesia juga ikut terpengaruhi terutama dengan adanya kebijakan dari pemerintah pada 1 April 2020. Kebijakan yang diperintahkan pemerintah merupakan upaya pencegahan atas penyebaran covid-19 di Indonesia, yang mengakibatkan industri food \& beverage tidak boleh melayani dine-in, namun hanya delivery, takeaway, dan drive thru. Selain itu, adanya kebijakan quarantine oleh pemerintah dan WHO (World Health Organization) yang menganjurkan masyarakat tidak keluar dari rumah, kecuali dalam keadaan mendesak. Hal ini menyebabkan Starbucks menjadi sepi pengunjung, beberapa gerai Starbucks di Indonesia bahkan ada yang diputuskan untuk ditutup sementara.

Namun dengan adanya terapan new normal oleh pemerintah, PT Sari Coffee Indonesia, sebagai pemegang lisensi Starbucks di Indonesia menyatakan bahwa akan mulai menerima konsumen untuk dine-in pada pertengahan bulan Juni 2020 di berbagai gerai Starbucks di Indonesia, dengan menerapkan new normal protocol yang berfokus pada physical distancing. (Aisyah, 2020).

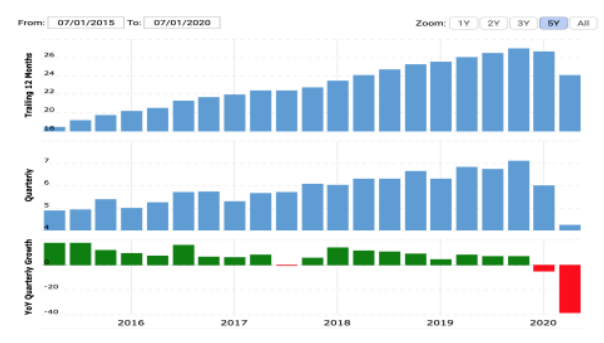

sumber:

https://www.macrotrends.net/stocks/charts/SBUX/starbuc ks/revenue

Gambar 1. Grafik penurunan pendapatan Starbucks
Berdasarkan grafik di atas, diketahui bahwa adanya penurunan pendapatan Starbucks yang cukup drastis. Pada Juni, 2019 pendapatan yang diperoleh Starbucks sebesar $\$ 6.823$ triliun. Sedangkan pada waktu yang sama Juni, 2020 pendapatan Starbucks jatuh ke angka $\$ 4.222$ triliun. Ini merupakan penurunan pendapatan Starbucks yang cukup drastis sejak September, 2017 yang mengalami penurunan sebesar -0,23\%. Sedangkan pada Juni, 2020 penurunan pendapatan sebesar $-38,12 \%$. Dengan adanya penurunan pendapatan maka dapat disimpulkan bahwa terjadi penurunan dalam hal 'keputusan pembelian' konsumen, terutama di masa covid-19. Walaupun Starbucks merupakan brand coffee shop terbesar di dunia. Namun Starbucks khususnya di Indonesia, tetap melakukan berbagai upaya seperti promosi penjualan yang diberikan setiap harinya dengan bentuk yang beragam, terutama di saat pandemi. Hal - hal yang telah disampaikan di atas menjadi pertimbangan yang menarik untuk dilakukannya penelitian. karena dapat dilihat walaupun Starbucks merupakan brand coffee shop terbesar di dunia, Starbucks tetap melakukan upaya promosi penjualan secara terus menerus setiap harinya terutama di masa pandemi covid-19. Rumusan masalah dalam penelitian dikemukakan peneliti sebagai berikut:

1. Apakah brand trust memiliki pengaruh terhadap keputusan pembelian konsumen pada masa pandemi covid-19?

2. Apakah promosi penjualan memiliki pengaruh terhadap keputusan pembelian konsumen pada masa pandemi covid-19?

Sedangkan, tujuan dari penelitian ini adalah untuk menganalisis pengaruh brand trust terhadap keputusan pembelian konsumen Starbucks serta menganalisis pengaruh promosi penjualan terhadap keputusan pembelian konsumen Starbucks.

\section{Brand Trust}

Menurut (Kotler \& Armstrong, 2016) brand trust atau kepercayaan merek adalah konsumen mempercayai suatu produk dengan segala resikonya karena adanya harapan atau ekspektasi tinggi terhadap merek tersebut akan memberikan hasil yang positif kepada konsumen sehingga akan menimbulkan kesetiaan dan kepercayaan terhadap suatu merek. Seorang individu yang telah menggunakan produk tersebut kemudian diikuti oleh orang lain, maka telah terbukti bahwa kualitas dari produk ini terjamin sehingga memunculkan rasa percaya pada produk tersebut.

Menurut (Adiwidjaja, 2017) brand trust atau kepercayaan merek, keputusan pembelian konsumen akan ditentukan terhadap merek dan dalam 
menciptakan hubungan-hubungan yang bernilai tinggi maka diperlukan kepercayaan.

Menurut (El Naggar \& Bendary, 2017) mengungkapkan bahwa brand trust diartikan sebagai perasaan tenang sementara interaksi dengan brand didasarkan pada persepsi bahwa brand tersebut bisa diandalkan sekaligus bertanggung jawab pada kepentingan konsumen.

\section{Promosi Penjualan (Sales Promotion)}

Promosi penjualan adalah kegiatan penjualan yang bersifat jangka pendek dan tidak dilakukan secara rutin dan juga tidak secara berulang, yang bertujuan untuk mendorong lebih kuat mempercepat respond pasar yang berbeda (Saladin, 2016).

Promosi penjualan merupakan kunci utama dalam pemasaran, yang bersifat jangka pendek dan dirancang untuk menarik pembelian produk atau layanan tertentu dengan lebih cepat oleh konsumen atau perdagangan menurut (Kotler \& Keller, 2016).

\section{Keputusan Pembelian}

Menurut (Soim et al., 2016) pada umumnya keputusan pembelian konsumen merupakan kebutuhan dan keinginan masa kini dan masa akan datang yang merupakan minat dari konsumen sendiri untuk membeli.

Menurut (Kotler \& Armstrong, 2016) keputusan pembelian merupakan bagian dari perilaku konsumen yang dimana studi mengenai bagaimana individu, kelompok, dan juga organisasi yang termasuk dalam memilih, membeli, menggunakan, dan bagaimana barang dan jasa, ide atau pengalaman tujuannya untuk memuaskan kebutuhan juga keinginan para konsumen.

\section{Hubungan Antar Variabel Brand Trust Terhadap Keputusan Pembelian Konsumen}

Penelitian (Adji, 2014) "Pengaruh Satisfaction dan Trust Terhadap Minat Pembelian Di Starbucks the Square Surabaya" salah satu tujuan penelitian ini untuk mengetahui pengaruh trust terhadap minat pembelian di Starbucks the Square Surabaya. Jenis penelitian yang digunakan adalah penelitian kausal (causal research) untuk mengetahui hubungan sebabakibat antar 2 variabel atau lebih untuk pengujian hipotesis pada penelitian ini menggunakan structural equation model (SEM). Sampel dalam penelitian diambil 200 responden. Hasil analisa penelitian didapatkan bahwa trust secara positif memiliki pengaruh signifikan terhadap minat pembelian Starbucks the Square Surabaya. Pihak manajemen ada baiknya melakukan peningkatan keramahan dan interaktif staff dengan konsumen seperti menawarkan rasa minuman agar dapat meningkatkan minat beli konsumen.

Penelitian (Rahmawati \& Nilowardono, 2018) menunjukkan bahwa kontribusi yang tinggi dari brand trust mempunyai pengaruh signifikan terhadap keputusan pembelian Royal Residence Surabaya Housing. Studi (Lantara, A. A. M. O., \& Pramudana, 2020) kepercayaan merek berpengaruh positif dan signifikan terhadap sikap konsumen. Sikap berpengaruh positif dan signifikan terhadap keputusan pembelian konsumen. Sikap memediasi pengaruh positif kepercayaan merek terhadap keputusan pembelian konsumen.

\section{Hubungan Antara Variabel Promosi Penjualan Terhadap Keputusan Pembelian Konsumen}

Penelitian (Arifah, 2018) hasil analisa penelitian menunjukkan bahwa promosi berpengaruh positif dan signifikan terhadap minat beli kembali konsumen. Pihak Starbucks Coffee Diponegoro Medan diharapkan mampu menawarkan produk yang menarik serta dapat memperjelas menu dan sesuai dengan kenyataan agar dapat menarik konsumen.

Penelitian (Hanifah \& Hartono, 2017). Hasil analisa penelitian menunjukkan bahwa sales promotion tumbler day mempunyai pengaruh positif pada keputusan pembelian konsumen di Starbucks JIExpo Kemayoran.

Penelitian (Nangoy \& Tumbuan, 2018) Dengan 75 responden, data yang diterima diolah dengan cara uji reliabilitas, asumsi klasik dan uji regresi linier berganda. Hasil analisa yang didapatkan yaitu promosi penjualan (sales promotion) sebagai variabel independent tidak berpengaruh terhadap keputusan pembelian konsumen. Penelitian (Augustinus, 2018) menyatakan bahwa terdapat pengaruh promosi penjualan terhadap minat beli kosumen.

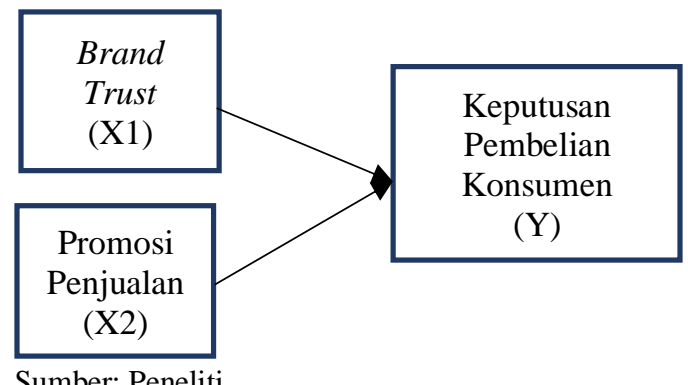

Sumber: Peneliti

Gambar 2. Kerangka Konseptual

H1: Variabel brand trust memiliki pengaruh positif terhadap keputusan pembelian konsumen pada masa pandemi covid-19.

H2: Variabel Promosi penjualan memiliki pengaruh positif terhadap keputusan pembelian konsumen pada masa pandemi covid-19.

H3: Variabel brand trust dan promosi penjualan memiliki pengaruh yang signifikan terhadap keputusan pembelian konsumen pada masa pandemi covid-19. 


\section{METODE PENELITIAN}

Penelitian ini menggunakan metode kuantitatif untuk menganalisis data yang diperoleh. Menurut (Sugiyono, 2016) Populasi adalah daerah generalisasi yang terdiri dari: objek ataupun subyek yang mempunyai kualitas dan ciri tertentu yang disetujui oleh peneliti untuk di analisa dan kemudian dibuat kesimpulannya. Populasi yang dimaksudkan dalam penelitian ini adalah konsumen Starbucks di Indonesia yang pernah mengunjungi ataupun melakukan pembelian produk dalam bentuk take away, dine - in, ataupun drive thru. Menurut (Sekaran \& Bougie, 2016) sampel adalah hanya bagian dari populasi yang termasuk dari beberapa anggota yang telah dipilih. Menurut (Sekaran \& Bougie, 2016) ukuran sampel dalam penelitian harus memiliki jumlah sampel minimum sepuluh kali jumlah pertanyaan yang dianalisis. Pada kuesioner penelitian ini terdapat 20 pertanyaan, dengan demikian minimum jumlah sampel yang dibutuhkan adalah 200 responden ( $20 \times 10)$.

Tabel 1

Tabel Kuesioner

\begin{tabular}{|c|c|c|}
\hline Variabel & Indikator & Sumber \\
\hline \multirow[t]{3}{*}{ Brand Trust } & $\begin{array}{l}\text { Saya percaya } \\
\text { Produk } \\
\text { starbucks } \\
\text { mampu } \\
\text { memenuhi } \\
\text { ekspetasi } \\
\text { kosumen di } \\
\text { masa covid } 19\end{array}$ & \multirow[t]{3}{*}{ (Arslan, 2013) } \\
\hline & $\begin{array}{l}\text { Produk } \\
\text { starbucks } \\
\text { mampu } \\
\text { memberikan } \\
\text { rasa aman dari } \\
\text { segi kualitas, } \\
\text { service di masa } \\
\text { covid } 19\end{array}$ & \\
\hline & $\begin{array}{l}\text { Starbucks } \\
\text { merupakan } \\
\text { merek yang } \\
\text { mampu } \\
\text { meningkatkan } \\
\text { kepercayaan } \\
\text { kepada } \\
\text { konsumen (jujur } \\
\text { kepada } \\
\text { pelanggan) } \\
\end{array}$ & \\
\hline \multirow[t]{2}{*}{$\begin{array}{l}\text { Promosi } \\
\text { Penjualan }\end{array}$} & $\begin{array}{l}\text { Saya puas } \\
\text { dengan } \\
\text { starbucks yang } \\
\text { sering } \\
\text { melakukan } \\
\text { promosi melalui } \\
\text { media sosial } \\
\text { pada masa covid } \\
19\end{array}$ & \multirow[t]{2}{*}{$\begin{array}{l}\text { (Kotler dan } \\
\text { Keller, 2012) }\end{array}$} \\
\hline & $\begin{array}{l}\text { Saya membeli } \\
\text { produk } \\
\text { starbucks ketika } \\
\text { melihat promosi } \\
\text { melalui media }\end{array}$ & \\
\hline
\end{tabular}

\begin{tabular}{|c|c|c|}
\hline & $\begin{array}{l}\text { sosial selama } \\
\text { covid } 19\end{array}$ & \\
\hline & \begin{tabular}{lr} 
Saya puas \\
dengan kualitas \\
promosi yang \\
dilakukan dan \\
produk yang \\
ditawarkan \\
starbucks coffee \\
\multicolumn{2}{l}{ saat covid 19}
\end{tabular} & \\
\hline & $\begin{array}{lr}\text { Saya } & \text { membeli } \\
\text { produk } & \\
\text { starbucks } & \text { dalam } \\
\text { jumlah lebih } \\
\text { banyak dari } \\
\text { yang dibutuhkan } \\
\text { pada r saat } \\
\text { promosi }\end{array}$ & \\
\hline & $\begin{array}{l}\text { Saya setuju } \\
\text { dengan waktu } \\
\text { yang ditentukan } \\
\text { oleh pihak } \\
\text { starbucks } \\
\text { (setuju dengan } \\
\text { kapan promosi } \\
\text { diberikan) } \\
\text { selama covid-19 }\end{array}$ & \\
\hline & \begin{tabular}{lr}
\multicolumn{3}{l}{ Saya memahami } \\
batas & waktu \\
promosi, yang \\
dilakukan oleh \\
pihak Starbucks \\
selamar masa \\
covid-19
\end{tabular} & \\
\hline & $\begin{array}{l}\text { Saya suka } \\
\text { dengan } \\
\text { ketepatan } \\
\text { Starbucks untuk } \\
\text { melakukan } \\
\text { promosi setiap } \\
\text { harinya } \\
\text { (termasuk pada } \\
\text { hari besar) }\end{array}$ & \\
\hline & $\begin{array}{l}\text { Saya melihat } \\
\text { program } \\
\text { promosi yang } \\
\text { dilakukan } \\
\text { starbucks sangat } \\
\text { baik dan tepat } \\
\text { pada sasaran } \\
\text { pada masa covid } \\
19\end{array}$ & \\
\hline $\begin{array}{l}\text { Keputusan } \\
\text { Pembelian }\end{array}$ & $\begin{array}{l}\text { Saya } \\
\text { memutuskan } \\
\text { untuk } \\
\text { melakukan } \\
\text { pembelian di } \\
\text { Starbucks } \\
\text { karena produk } \\
\text { kopi yang } \\
\text { ditawarkan } \\
\end{array}$ & $\begin{array}{l}\text { (Schiffman and } \\
\text { Kanuk, 2015) }\end{array}$ \\
\hline
\end{tabular}




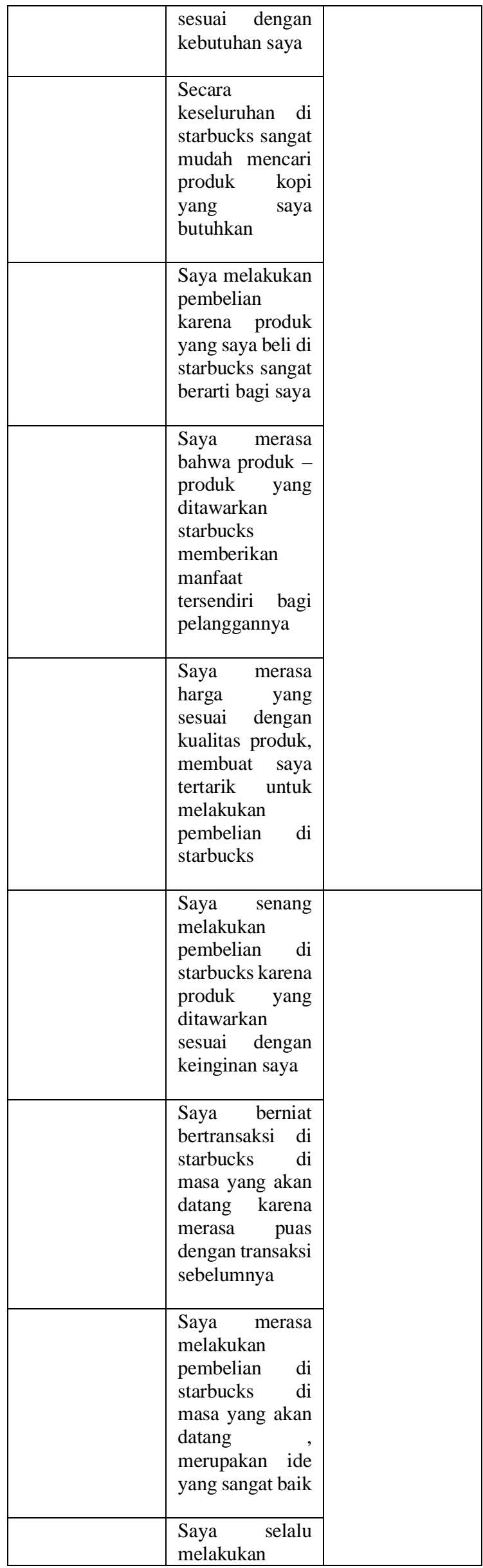

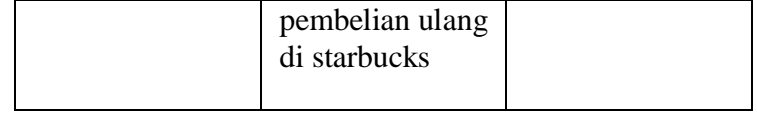

Sumber: Penelitian tahun 2020

Teknik yang akan digunakan dalam pengumpulan data menggunakan teknik survei melalui penyebaran kuesioner dengan menggunakan skala pengukuran skala likert tujuh poin (sangat setuju - sangat tidak setuju). Menurut (Sugiyono, 2016) Kuesioner merupakan teknik pengumpulan data yang dilakukan dengan cara memberi seperangkat pertanyaan atau pertanyaan tertulis kepada responden untuk dijawabnya.

Kuesioner yang digunakan dalam hal ini adalah kuesioner tertutup yakni kuesioner yang sudah disediakan jawabannya, sehingga responden tinggal memilih dan menjawab secara langsung. Penyebaran kuesioner yang difokuskan kepada kepada para konsumen pembelian produk Starbucks mengenai keputusan pembelian Product Starbucks pada Masa Covid-19.

Menurut (Sugiyono, 2016) Variabel Dependen atau terikat sering disebut sebagai variabel output, kriteria, konsekuen adalah variabel yang dipengaruhi atau yang menjadi akibat, karena adanya variabel bebas. Menurut (Sugiyono, 2016) Variabel Independen sering disebut sebagai variable; stimulus,predictor, antecedent adalah variable yang mempengaruhi atau yang menjadi sebab perubahannya atau timbulnya variable dependen (terikat).Terdapat tiga variabel yang akan diteliti yaitu Variabel bebas brand trust (X1) dan promosi penjualan (X2) yang memengaruhi variabel terikat yaitu keputusan pembelian konsumen (Y) terhadap produk Starbucks pada masa covid-19. Metode analisis data yang digunakan adalah analisis deskriptif, uji validitas dan uji reliabilitas, uji regresi linier berganda, uji koefisien determinasi dan uji $\mathrm{F}$ serta uji t.

\section{HASIL DAN PEMBAHASAN}

Pada penelitian ini, telah disebarkan 200 kuesioner kepada konsumen Starbucks yang pernah mengunjungi ataupun membeli produk secara tidak langsung. Semua kuesioner disebarkan atau dibagi secara online menggunakan google forms yang diisi oleh para responden.

Dari total 200 responden, dapat diketahui profil responden terdapat $91(45,5 \%)$ pria dan $109(54,5 \%)$ wanita yang mengisi responden. Sedangkan dari segi rentang usia, 15-18 tahun terdapat 23 responden (11,5\%), 19-22 tahun terdapat 145 responden (72,5\%), 23-25 tahun terdapat 11 responden $(5,5 \%)$ dan $>25$ 
tahun terdapat 21 responden $(10,5 \%)$.

Tabel 2.

Hasil Uji Reliabilitas

\begin{tabular}{|l|c|c|c|}
\hline \multicolumn{1}{|c|}{ Variabel } & $\begin{array}{c}\text { Cornbach's } \\
\text { Alpha }\end{array}$ & Items & Keterangan \\
\hline Brand Trust & .821 & 3 & Reliabel \\
\hline $\begin{array}{l}\text { Promosi } \\
\text { Penjualan }\end{array}$ & .887 & 8 & Reliabel \\
\hline $\begin{array}{l}\text { Keputusan } \\
\text { Pembelian }\end{array}$ & .939 & 9 & Reliabel \\
\hline
\end{tabular}

Sumber: Hasil Olahan Data SPSS (2020)

Dari Tabel 2 cornbach 's alpha tiap variabel lebih besar dari 0,6 yang berarti menunjukkan reliabel. Cornbach's alpha untuk variabel Brand Trust adalah 0,821, untuk variabel Promosi Penjualan adalah 0,887, sedangkan variabel Keputusan Pembelian adalah 0,939 .

Tabel 3.

Hasil Uji Validitas Brand Trust

\begin{tabular}{|c|c|c|c|}
\hline Variabel & $\begin{array}{c}\text { Scale Mean } \\
\text { Item Deleted }\end{array}$ & $\begin{array}{c}\text { If Scale } \\
\text { If Item }\end{array}$ & $\begin{array}{c}\text { Corrected } \\
\text { Item-Total } \\
\text { Correlation }\end{array}$ \\
\hline BT 1 & 12.0900 & 3.148 & .624 \\
\hline BT 2 & 12.0300 & 3.125 & .717 \\
\hline BT 3 & 11.8600 & 3.693 & .709 \\
\hline
\end{tabular}

Sumber: Hasil Olahan Data SPSS (2020)

Pada Tabel 3 dapat dilihat seluruh indikator dari Brand Trust memiliki nilai corrected item-total correlation yang lebih dari 0.3. Maka, semua indikator atau butir pertanyaan dinyatakan valid.

Tabel 4.

Hasil Uji Validitas Promosi Penjualan

\begin{tabular}{|c|c|c|c|}
\hline Variabel & $\begin{array}{c}\text { Scale Mean } \\
\text { Item Deleted }\end{array}$ & $\begin{array}{c}\text { If Scale If } \\
\text { Item }\end{array}$ & $\begin{array}{c}\text { Corrected } \\
\text { Item-Total } \\
\text { Correlation }\end{array}$ \\
\hline PP 1 & 37.6850 & 61.674 & .624 \\
\hline PP 2 & 38.6800 & 52.500 & .697 \\
\hline PP 3 & 37.9450 & 58.223 & .760 \\
\hline PP 4 & 38.9950 & 54.739 & .550 \\
\hline PP 5 & 38.1600 & 59.663 & .663 \\
\hline PP 6 & 38.2250 & 54.969 & .770 \\
\hline PP 7 & 37.8450 & 59.438 & .669 \\
\hline PP 8 & 37.9100 & 60.042 & .701 \\
\hline
\end{tabular}

Sumber: Hasil Olahan Data SPSS (2020)

Seluruh indikator dari Promosi Penjualan memiliki nilai corrected item-total correlation yang lebih dari 0.3. Maka, semua indikator atau butir pertanyaan dinyatakan valid.
Tabel 5.

Hasil Uji Validitas Keputusan Pembelian

\begin{tabular}{|l|l|l|l|}
\hline Variabel & $\begin{array}{l}\text { Scale Mean } \\
\text { Item Seleted }\end{array}$ & $\begin{array}{l}\text { If Scale } \\
\text { If Item }\end{array}$ & $\begin{array}{l}\text { Corrected } \\
\text { Item-Total } \\
\text { Correlation }\end{array}$ \\
\hline KP 1 & 43.7150 & 3.148 & .624 \\
\hline KP 2 & 43.5700 & 3.125 & .717 \\
\hline KP 3 & 44.2550 & 3.639 & .709 \\
\hline KP 4 & 43.8450 & 90.423 & .688 \\
\hline KP 5 & 43.9050 & 87.544 & .715 \\
\hline KP 6 & 43.4550 & 88.611 & .808 \\
\hline KP 7 & 43.5200 & 87.447 & .793 \\
\hline KP 8 & 43.6700 & 86.363 & .844 \\
\hline KP 9 & 43.7850 & 86.129 & .753 \\
\hline
\end{tabular}

Sumber: Hasil Olahan Data SPSS (2020)

Tabel 5 memperlihatkan indikator dari Keputusan Pembelian mempunyai nilai corrected item-total correlation yang lebih dari 0.3. Maka, semua indikator atau butir pertanyaan dinyatakan valid.

Tabel 6.

Hasil Uji Regresi Linier Berganda

\begin{tabular}{|c|c|c|c|c|}
\hline \multirow[t]{2}{*}{ Model } & \multicolumn{2}{|c|}{$\begin{array}{l}\text { Unstandardizes } \\
\text { Coefficient }\end{array}$} & \multirow[t]{2}{*}{$\begin{array}{l}\text { Standardized } \\
\text { Coefficients }\end{array}$} & \multirow[t]{2}{*}{ Sig. } \\
\hline & $\mathrm{B}$ & $\begin{array}{l}\text { Std. } \\
\text { Error }\end{array}$ & & \\
\hline (Constant) & -.097 & 3.690 & & .979 \\
\hline BT & 1.204 & .231 & .300 & .000 \\
\hline PP & .634 & .070 & .521 & .000 \\
\hline
\end{tabular}

a. Dependent Variable: Keputusan Pembelian Sumber: Hasil Olahan Data SPSS (2020)

Rumusan persamaan regresi berganda di atas, sebagai berikut:

$\mathrm{Y}=\alpha+\beta 1 X 1+\beta 2 X 2+e$

$=-0.097+1.204 \mathrm{BT}+0.634 \mathrm{PP}+\mathrm{e}$

Persamaan ini menggambarkan bahwa:

1. Konstanta (a) $=-0,097$, artinya jika Brand Trust (X1) dan Promosi Penjualan (X2) tidak mengalami perubahan atau $=0$ maka besarnya Keputusan Pembelian $(\mathrm{Y})=-0.097$ sebagai satu kesatuan.

2. Jika variabel brand trust (X1) mengalami perubahan sebesar 1 satuan, sementara variabel promosi penjualan (X2) tetap, maka keputusan pembelian (Y) akan mengalami peningkatan sebesar 1,204 satuan.

3. Jika variabel promosi penjualan (X2) mengalami perubahan sebesar 1 satuan, sementara variabel brand trust (X1) tetap, maka keputusan pembelian (Y) akan mengalami peningkatan sebesar 0,634 satuan. 
Tabel 7.

Koefisien Determinasi $\left(R^{2}\right)$

\begin{tabular}{|c|c|c|c|}
\hline $\mathrm{R}$ & R Square & $\begin{array}{c}\text { Adjusted R } \\
\text { Square }\end{array}$ & $\begin{array}{c}\text { Std. Error } \\
\text { of the } \\
\text { Estimate }\end{array}$ \\
\hline $.724^{\mathrm{a}}$ & .524 & .520 & 7.26037 \\
\hline
\end{tabular}

Sumber: Hasil Olahan Data SPSS (2020)

Melalui perhitungan yang dilakukan dengan software SPSS, didapatkan bahwa nilai $\mathrm{R}$ sebesar 0.524 artinya mempunyai hubungan yang erat atau kuat. Kemudian nilai adjusted $R$ square adalah 0,520 atau koefisien determinasi $\left(R^{2}\right)$ sebesar 0,520 . Hal ini memperlihatkan bahwa kontribusi variabel: brand trust (X1) dan promosi penjualan (X2) indikator Brand Trust dan Promosi penjualan terhadap variabel Keputusan pembelian sebesar $52 \%$ dan sisanya sebesar $48 \%$ dipengaruhi oleh variabel lainnya diluar penelitian.

Tabel 8.

Hasil Uji F

\begin{tabular}{|l|l|l|l|l|l|}
\hline Model & $\begin{array}{l}\text { Sum of } \\
\text { Squares }\end{array}$ & df & $\begin{array}{l}\text { Mean } \\
\text { Square }\end{array}$ & F & Sig. \\
\hline $\begin{array}{l}\text { Regres } \\
\text { sion }\end{array}$ & 11451.300 & 2 & $\begin{array}{l}5725.65 \\
0\end{array}$ & $\begin{array}{l}108.61 \\
9\end{array}$ & $.000^{b}$ \\
\hline $\begin{array}{l}\text { Residu } \\
\text { al }\end{array}$ & 10384.455 & 197 & 52.713 & & \\
\hline Total & 21835.755 & 199 & & & \\
\hline
\end{tabular}

a. Dependent Variable: Keputusan Pembelian

b. Predictors: (Constant), Brand Trust, Promosi Penjualan

Sumber: Hasil Olahan Data (2020)

Pada Tabel 8 dapat dilihat dari output SPSS bahwa signifikansi $F$ sebesar 0,000 yang berarti Sig.<0,05. Membuktikan bahwa brand trust dan promosi penjualan berpengaruh terhadap keputusan pembelian. Kemudian $F_{\text {hitung }}$ menunjukkan hasil 108.619. Untuk nilai $\mathrm{f}$ tabel dengan df $1=2$ dan df $2=$ 197 adalah 3,040. Maka $F_{\text {hitung }}>F_{\text {tabel }}$ yang berarti menerima H1 dan Ho ditolak, sehingga dapat dikatakan bahwa minimal satu variabel dari brand trust dan promosi penjualan yang berpengaruh terhadap keputusan pembelian konsumen Starbucks.
Tabel 9.

Hasil Uji t

\begin{tabular}{|c|c|c|c|c|c|}
\hline Model & \multicolumn{2}{|c|}{$\begin{array}{c}\text { Unstandardized } \\
\text { Coefficients }\end{array}$} & $\begin{array}{c}\text { Standa } \\
\text { rdized } \\
\text { Coeffi } \\
\text { cients }\end{array}$ & t & Sig. \\
\cline { 2 - 5 } & B & $\begin{array}{c}\text { Std. } \\
\text { Error }\end{array}$ & Beta & & \\
\hline $\begin{array}{c}\text { (Constan } \\
\text { t) }\end{array}$ & -.097 & 3.690 & & -.026 & .979 \\
\hline BT & 1.204 & .231 & .300 & 5.216 & .000 \\
\hline PP & .634 & .070 & .521 & 9.041 & .000 \\
\hline
\end{tabular}

a. Dependent Variable: Keputusan Pembelian Sumber: Hasil Olahan Data SPSS (2020)

Pada tabel 9, dari hasil uji t dapat dilihat bahwa variabel brand trust dan promosi penjualan secara parsial berpengaruh signifikan terhadap keputusan pembelian, hal ini dapat dilihat dari nilai $t_{\text {hitung }}=$ $0.026<t_{\text {tabel }}=1,972$ yang berarti Ho dapat ditolak dan $\mathrm{H} 1$ diterima. Variabel brand trust mempunyai $t_{\text {hitung }}$ g $5.216>t_{\text {tabel }}(1,972)$ dan nilai sig sebesar 0,000 yang artinya sig $<0,05$.

Maka, dapat disimpulkan adanya pengaruh signifikan terhadap keputusan pembelian. Kemudian untuk variabel promosi penjualan mempunyai $t_{\text {hitung }}$ 9,041 > $t_{\text {tabel }}(1972)$ dan nilai sig sebesar 0,000 yang artinya sig $<0,05$. Maka, dapat disimpulkan bahwa variabel promosi penjualan berpengaruh signifikan terhadap keputusan pembelian konsumen Starbucks.

\section{KESIMPULAN}

Berdasarkan hasil uji hipotesis dan analisis regresi yang dilakukan peneliti, menunjukkan bahwa variabel Promosi Penjualan dan Brand Trust memiliki pengaruh yang signifikan terhadap keputusan pembelian konsumen Starbucks Coffee Indonesia.

Antara kedua variabel, Brand Trust merupakan variabel yang menunjukkan pengaruh paling signifikan dalam penelitian ini, terutama di masa covid-19 dimana konsumen lebih tertarik dengan brand Starbucks Coffee dibandingkan merek coffee shop lainnya di masa pandemi.dikarenakan brand image starbucks coffee lebih kuat dibandingkan dengan brand image lainnya sehingga menyebabkan brand trust starbucks paling tinggi.

Dengan demikian, ada baiknya jika Starbucks di Indonesia lebih berfokus pada peningkatan promosi penjualan produk mereka terutama pada masa covid-19 dengan memperluas cakupan konsumen dan kerja sama yang lebih luas dengan berbagai pihak ketiga, sehingga dapat mengembangkan brand serta promosi penjualan dalam satu waktu. 


\section{REFERENSI}

Adiwidjaja, A. J. (2017). Pengaruh Brand Image Dan Brand Trust Terhadap Keputusan Pembelian Sepatu Converse. Agora - Online Graduate Humanities Journal, 5(3).

Adji, J. (2014). Pengaruh Satisfaction dan Trust Terhadap Minat Pembelian di Starbucks The Square Surabaya. Jurnal Strategi Pemasaran, 2.

Aisyah, Y. (2020). Bagaimana Protokol New Normal di Starbucks Indonesia?

Arifah, P. Y. (2018). Pengaruh Kualitas Produk, Promosi, dan Loyalitas Pelanggan Terhadap Minat Membeli Kembali Starbucks Coffee di Jl . Diponegoro medan. Universitas Sumatera Utara.

Arslan, G. \& Z. (2013). Examining Perceived Risk and Its Influenceon Attitudes: A Study on Private Label Consumers in Turkey. Asian Social Science, Vol. 9, No. 4.

Augustinus, R. (2018). Analisa Promosi Penjualan terhadap Minat Beli Konsumen Starbucks Coffee Di Bandung. Universitas Kristen Maranatha.

El Naggar, R. A. A., \& Bendary, N. (2017). The Impact of Experience and Brand trust on Brand loyalty, while considering the mediating effect of brand Equity dimensions, an empirical study on mobile operator subscribers in Egypt. The Business and Management Revieq, 9(2), 16-25.

Hanifah, R. D., \& Hartono, F. (2017). Pengaruh Sales PromotionTumbler Day terhadap Keputusan Pembelian Konsumen di Starbucks Coffee JIExpo Kemayoran. Jurnal Hospitality dan Pariwisata, 3(2).

Kotler dan Keller. (2012). Manajemen Pemasaran Perspektif Asia, Buku Dua, Edisi Pertama,. Andy, Yogyakarta.

Kotler, P., \& Armstrong, G. (2016). Principle of Marketing (15 ed.). Pearson Education. inc.

Kotler, P., \& Keller, K. L. (2016). Marketing Management (15 ed.). Pretice Hall.

Lantara, A. A. M. O., \& Pramudana, K. A. S. (2020). Peran Sikap Memediasi Pengaruh Brand Trust Terhadap Keputusan Pembelian Konsumen. EJurnal Manajemen Universitas Udayana, 9(1),
218.

https://doi.org/10.24843/ejmunud.2020.v09.i0 1.p12.

Nangoy, C. L., \& Tumbuan, W. J. F. A. (2018). The Effect Of Advertising And Sales Promotion On Consumer Buying Decision Of Indovision TV Cable Provider. EMBA, 6(3).

Rahmawati, Y., \& Nilowardono, S. (2018). The Effect Of Product Quality, Brand Trust, Price And Sales Promotion On Purchase Decisions On Royal Residence Surabaya (Case Study In PT. Propnex Realti Visit). International Journal of Integrated Education, Engineering and Business, 1(1).

Saladin, D. (2016). Analisis Pengaruh Inovasi Produk Dan Sales Promotion Terhadap Keputusan Pembelian di Sandy Jaya Furniture Jepara. Jurnal Studi Manajemen Bisnis.

Schiffman and Kanuk. (2015). Consumer Behavior (11th Editi). Pearson Education.

Sekaran, U., \& Bougie, R. (2016). Research Methods for Business: A Skill Building Approach (7 ed.). John Wiley \& Sons.

Soim, F. M., Suharyono, \& Abdillah, Y. (2016). Pengaruh Brand Image Terhadap Keputusan Pembelian (Studi pada Pembeli Kartu Perdana Simpati di Booth Telkomsel Matos). Jurnal Administrasi Bisnis, 35(1), 146-153.

Sugiyono. (2014). Metode Penelitian Pendidikan pendekatan Kuantitatif, Kualitatif dan R\&D. In METODE PENELITIAN ILMIAH.

Sugiyono. (2016). Metode Penelitian Kuantitatif,Kualitatif,dan R\&D. In Alfabeta, $c v$.

Sumarsono, D. (2015). Luar Biasa Bisnis Restoran Indonesia (I. Hardiman (ed.)). PT Gramedia Pustaka Utama. 